\title{
Opening Spaces of Resistance in the Corporatized Cultural Institution: Liberate Tate and the Art Not Oil Coalition
}

\author{
Emma Mahony*
}

\begin{abstract}
In the current economic climate where state subsidies for the arts have been steadily eroded, there is a consensus in support of the good of corporate sponsorship for cultural institutions. This article seeks to problematize this consensus by critiquing the strategies that corporations employ in their sponsorship agreements with public cultural institutions and opening up a discussion around the ethical issues this poses for their recipients. It then examines how a coalition of subversive arts collectives, that come together under the banner 'Art Not Oil', have begun to successfully shatter this consensus through a sustained campaign of unauthorized live art interventions enacted inside cultural institutions. It argues that the unique strategy of resistance they employ operates at an interstitial distance to the public cultural institutions they target, from where they open up spaces of resistance ultimately capable of rewriting the cultural sectors' corporatized value system.
\end{abstract}

Key Words: Corporate sponsorship, Public cultural sector, Liberate Tate, Simon Critchley, Interstitial distance

\section{Introduction}

As 200 million gallons of crude oil spilled into the Gulf of Mexico from the BP operated Deepwater Horizon oil rig in the Spring of 2010, the artist collective Liberate Tate began what would become a regular series of creative interventions opposing Tate's sponsorship agreement with BP. For the first of these actions, License to Spill (2010), the collective gatecrashed a party hosted by Tate to celebrate the twentieth anniversary of their relationship with BP and staged a reenactment of the Deepwater Horizon Disaster in the middle of the Duveen Galleries. The action, which was realized by two female members of the group, involved releasing bags of an oil-like substance from under the skirts of their party dresses, onto the gallery floor. In a riff on the words of then BP CEO Tony Hayward who had remarked that 'The Gulf of Mexico is a very big ocean. The amount of volume of oil and dispersant we are putting into it is tiny in relation to the total volume of water' (Webb 2010), one of the performers announced that 'Compared to the size of the gallery this is a tiny spill'. Her companion added that they would have the mess 'cleaned by up August', echoing the comment made by current CEO Robert Dudley in response to demands for a timeline for the clean-up. The duo then proceeded to make a half-hearted attempt to clean up the mess by using their high-heeled shoes to scoop the oil into their handbags, echoing what was largely perceived to be the ineffectiveness of BP's clean-up attempts in the Gulf of Mexico. On the first anniversary of the oil spill, Liberate Tate returned to Tate Britain to stage Human Cost (2011). In this action two female performers poured the same oil-like substance over the naked body of a third male performer who lay curled in a foetal position in the middle of the gallery floor, recalling the fate of marine wildlife in the Gulf of Mexico whose bodies had been covered in the oil slick. Despite interruptions from Tate security staff, who erected a cordon around the performers, the action lasted for 87 minutes to commemorate the 87 days during which oil continued to flow into the Gulf of Mexico before BP engineers succeeded in stopping the leak.

The purpose of these and Liberate Tate's many other creative interventions in Tate's two London branches (Tate Britain and Tate Modern) was to focus public attention on the 
inconsistencies between the ethical and environmentally friendly position Tate claims to adopt, ${ }^{1}$ and its twenty year relationship with $\mathrm{BP}$, a corporation that has been found guilty of multiple ecological and human rights infringements. ${ }^{2}$

Liberate Tate's call on Tate to sever its relationship with BP was quickly followed by the emergence of other grass-roots arts collectives including The Reclaim Shakespeare Company, Shell Out Sounds, BP or Not BP and BP Out of Opera. All of these collectives shared a common goal of pressuring public sector cultural institutions into severing their sponsorship agreements with fossil fuel corporations.

Although focused on oil giants BP and Shell, the actions of these collectives contributed to a wider debate (Wu 2003; Möntmann 2006, 2008; Davies 2012; Trowell 2013; Hewison 2014; Jelenik 2014; Evans 2015) in Britain and across Europe about the impacts of corporate sponsorship on public cultural institutions. The backdrop to this debate was a climate of budget cuts and austerity politics across the public cultural sector in Europe, where many institutions were expected to augment their state subsidies through both revenue generation and corporate sponsorship. In the UK, New Labour introduced match funding stipulations, whereby public cultural institutions applying for funding from Arts Council England (ACE), are required to raise equivalent funding from the private sector in order to qualify for subsidies. ${ }^{3}$

While the actions of these collectives succeeded in producing a wide body of public opinion in support of their position - including high profile figures like Naomi Klein, Brian Holmes and Lucy R Lippard - they equally incited very negative responses from within the public cultural sector. One of the most vociferous of these critiques was voiced by art critic for The Guardian, Jonathan Jones, who described Liberate Tate's campaign as '[...] the stupidest and most misplaced of supposedly radical campaigns' (2010). The counter argument that Jones proffered was that in times of austerity, public museums should grab funding wherever it comes from, as he put it: 'If they can get money from Satan himself, they should take it' (2010). Jones's stance was reiterated and underscored during a panel discussion on the future of arts funding in Britain entitled Public Art Private Money, which took place in London's Institute for Contemporary Arts (ICA) in September 2010. Although the press release for the event implied that its agenda was to problematize private sector sponsorship of the arts, the panel reached a unanimous consensus in support of the need for public art institutions to unquestioningly accept, and indeed, embrace corporate sponsorship. This outcome was not entirely unexpected, however, given the bias of the panel, which comprised of outspoken advocates of private sector funding for the arts including Alex Beard, deputy director of Tate, Christopher Frayling, former chairman of Arts Council England, and Colin Tweedy the Chief Executive of the then state subsidized organization, Arts \& Business.

As the consensus of opinion that emerged from the ICA panel discussion suggests, many of the voices dominating the debate on the future of cultural funding in Europe, are unwilling to acknowledge that corporate sponsorship can impact negatively on the public cultural landscape. In fact Colin Tweedy commented that 'I don't think there's any way we can say the arts scene has been distorted by corporate money' (cited in Saner and Khaleeli 2010). This is not a position this author shares, having worked as a curator and exhibition organizer at the Hayward Gallery in London's Southbank Centre between 2001 and 2008, where I observed firsthand how the cumulative effect of diminishing state subsidies, coupled with governmental pressure to increase revenue from the private sector, resulted in senior management pursuing an unashamedly commercial agenda that eclipsed the critical cultural platform upon which the institution once operated. During my time there, and in line with New Labour's cultural policy where the 'success' of public art institutions was increasingly measured in terms of audience figures rather than the social, cultural and pedagogical value they generate, the focus of the Hayward Gallery programme shifted from challenging and niche exhibitions, ${ }^{4}$ to exhibitions with popular appeal, ${ }^{5}$ intended to both increase attendance and ticket revenue and attract corporate sponsors. The changes that occurred during my time at the SBC could also more generally be observed across the British public cultural sector.

When the subversive collectives I discuss began targeting cultural institutions they quickly realized the enormity of the task they faced, but this did not deter them. In fact, Tate, the National Portrait Gallery, the British Museum and the Royal Opera House chose to renew their sponsorship deal with BP for a further five years in 2011 in spite of the high-profile actions 
of these collectives and the press they generated during 2010. Defending Tate's decision to renew their sponsorship relationship with BP, Tate director Nick Serota stated: '[The Board has] thought very carefully about this and decided that it was the right thing to do' (cited in Miliard 2012).

Reacting to this defeat in 2011, these collectives ramped up the pressure and focused on ensuring that the cultural institutions they were targeting did not renew their sponsorship agreements again in 2016. This article examines the unique strategy of resistance these collectives employed, one that was enacted from within the public sector cultural institutions they were targeting, but at an interstitial, or internal distance to them. Before I examine what this strategy entailed, it is necessary to first interrogate why these collectives are so invested in severing corporate relationships with public cultural institutions. To do so, this article will begin by critiquing the strategies that corporations have used in their sponsorship arrangements, before focusing on the ethical issues this poses for cultural institutions, their staff and publics.

\section{Why corporations sponsor the arts}

In 2011 the Conservative and Liberal Democratic Coalition government announced a 'Year of Cultural Philanthropy in Britain'. Their use of the term 'philanthropy' in this context is misleading insofar as it describes disinterested giving, where in fact the UK government were seeking to stimulate business and corporate sponsorship of culture. Sponsorship, unlike philanthropy, as McNicholas (2004) points out, is a strategic business partnership where both the donor and the recipient benefit from the relationship.

In the case of corporate sponsorship it is the donor who tends to benefit the most from the agreement, even though their financial benefit may be deferred. Often, the most valuable aspect of cultural sponsorship to a business or corporation is the manner in which it enables the donor to construct a socially acceptable identity through a process of image transfer. This is particularly valuable for companies whose activities are perceived to be unethical or harmful to health or the environment, such as the tobacco, alcohol, weapons and, as discussed in this article, fossil fuel industries. By virtue of aligning their tarnished identities with those of highly respected public sector cultural institutions, companies like these can mitigate against some of the negative aspects of their business dealings. In the 1980s Imperial Tobacco frequently funded cultural institutions in the UK including Royal Opera House, and the American tobacco company Philip Morris was also a major supporter of the arts, both in the US and Europe where most noteably the companied sponsored the seminal exhibition When Attitudes Become Form curated by Harald Szeemann at the Kunsthalle Bern, Switzerland in 1964. Questioned retrospectively about the reasons why Philip Morris sponsored the arts, the company's chief executive George Weissman made the following frank admission: 'The fundamental interest of business in art is self-interest [...] Our decision to promote art was not determined by the indigence or the situation of the art scene. Our sole desire was to be better than our competitors' (cited in Butin 1998: 7).

While pressure from anti-smoking groups forced cultural institutions to sever their longstanding relationships with tobacco companies in the mid-90s, today fossil fuel companies guilty of environmentally damaging activities and human rights violations - most notably BP and Shell - continue to fund a portfolio of cultural institutions. In particular, sponsorship deals such as BP's support of London's Tate Britain, The National Portrait Gallery and Royal Opera House, has enabled the company to divert attention away from its unethical business practices in the countries where its product is extracted or manufactured, by galvanizing popular support in countries where its product is consumed. This process is more commonly referred to as purchasing the 'social license' to operate, ${ }^{6}$ 'greenwashing' or 'artwashing' (Evans 2015: 13).

A further valuable aspect of the sponsorship deal to business executives is the access it grants them to the political apparatuses of state power and the means therein to turn the cultural capital they have amassed into political power. Margaret Thatcher was fully aware of this attraction when she rewarded corporate sponsorship by inviting CEOs of donor corporations to exclusive government receptions in cultural institutions where they were afforded the opportunity to mingle with government officials, policy makers and members of the British Royal Family (Wu 2003: 16, 48). 
Such gatherings provide important points of egress for CEOs wishing to engineer the political circumstances in which their businesses are most likely to prosper. Oil companies like $\mathrm{BP}$ and Shell have been known to strategically sponsor exhibitions that have a direct connection with the countries in which they have business interests, for example in 2014 Shell sponsored the exhibition Russian Landscape in the Age of Tolstoy at the National Gallery.

It is increasingly argued (Wu 2003; Lee 2011; Trowell 2013; Evans 2015) that the long term benefits accrued by corporations when they 'invest' in cultural institutions greatly outweigh the short-term benefits reaped by the cultural institutions. This imbalance is particularly evident in the amount of positive publicity a corporation receives proportionate to its investment. In the case of BP, in return for what has recently been revealed to be an average bequest of $£ 224,000$ a year (approximately 0.3 per cent of Tate's annual turnover), their logos were displayed on banners on the exterior of the building, on extensive signage inside the building as well as on all collection related printed matter. While one could argue that a logo is relatively discrete and unobtrusive, through subliminal repetition ' $[. .$.$] these symbols create resonance and power$ by short, sharp, regular appearances in contexts that give them value' (Marriott cited in Lee 2011: 15). Their value, then, is improved by association with these cultural institutions: BP's deceptively innocuous green and gold Helios, for example, has been synonymous with the 'New Displays' of the permanent collection at Tate Britain since 1990.

In 2013, when Tate Britain re-opened its doors after major refurbishment works, BP's exposure within the institution reached its zenith with the controversial re-branding of its permanent collection as BP Walk Through British Art. ${ }^{7}$ Such a move on Tate's part makes it appear as though it would not have been possible for Tate to maintain free access to its public collection without BP's support, a claim that is questionable, however, given that a condition of Tate's Grant-in-Aid - which has averaged 40 per cent of Tate's annual income over the past ten years - is to maintain free access to its public collections (Evans 2015: 52).

\section{The price of corporate sponsorship}

By virtue of accepting sponsorship from corporations with unethical, environmentally damaging or commercially aggressive business activities, public cultural institutions play a role in sanctioning the activities of these corporations. Furthermore, since approximately 40 per cent of the revenue these British institutions receive under their NPDP status comes from the public purse, British gallery goers and taxpayers are also implicated in the endorsement process. The question of ethics does not appear to be high on the agenda of the key players at the helm of these institutions, however. As Frayling unashamedly advises: 'The first person you go to [for sponsorship] is someone with an image problem' (cited in Trowell 2013: 7). To this Nicolas Serota, director of Tate adds: 'There's no money that is completely pure' (cited in Clarke et al. 2011: 41).

An argument frequently proffered in support of accepting sponsorship from corporations engaged in unethical activities is that their 'dirty' money is effectively transformed into 'good' money by virtue of being donated to a worthy cause. Reiterating a comment made by the founding chair of Arts \& Business in 1976, Tweedy states: 'Wherever the money comes from - it can be rolled by the Mafia - if it goes to the arts it becomes good money' (cited in Trowell 2013: 8). While there is no question that cultural organizations need to augment their state subsidies, by accepting dirty money, they are legitimizing the corporations involved. A case in point was Shell's sponsorship of the National Wildlife Photographer of the Year Award at the Natural History Museum between 2006 and 2008, which, while perceived in some circles to be putting bad money to a good use, was simultaneously endorsing the destruction of the very same wildlife that the award was attempting to glorify.

Another equally contentious issue that corporate sponsorship gives rise to is censorship. While there is unquestionably a lengthy history of art and culture being instrumentalized by its patrons (from the church to the monarchy, to dictatorial nation states under National Socialism and communism, and more recently New Labour's Third Way cultural policy), since the late 1960s the public art institution has been relatively tolerant and even welcoming of anti-institutional, anti-state and anti-capitalist critique, as the history of institutional critique attests. The fundamental difference, then, between Britain's arm's length state subsidies for 
culture and corporate sponsorship, is that the latter does not adhere to the belief that one of the roles of the arts and culture is to hold society to account, and that this critical function should be supported.

Corporate censorship of art and culture is a difficult issue to prove, however, as it tends to happen behind the scenes and the public is often none-the-wiser. As Kevin Smith of Platform points out: 'We will never have conclusive evidence of what has not been programmed, who was not invited, which work has not been made' (2012). A case in point is an instance of behind-the-scenes censorship I witnessed whilst working as a curator at the Hayward Gallery, when the corporate sponsors of a group exhibition put pressure on senior management to remove a work from the exhibition on the grounds that it did not align with their business ethos. Despite a consensus amongst the curatorial staff that the demand was both unreasonable and ungrounded, senior management eventually capitulated for fear that the sponsor might withdraw their funds.

One of the rare instances of corporate censorship that came to public attention in recent years pertains to a semi-permanent installation by British artist Chris Drury commissioned for the grounds of the University of Wyoming Art Museum. The installation, Carbon Sink: What Goes Around Comes Around (2011), took the form of 36-foot-in-diameter whirlpool arrangement of coal and logs taken from local trees that had died as a result of a pine beetle infestation (an epidemic which has been linked to global warming). In this case, executives of fossil fuel companies (including Marathon Oil and Arch Coal) and state legislators put pressure on the University of Wyoming Art Museum to remove Drury's installation on the grounds that the manner in which it made a connection between the activities of local coal, oil and gas mining industries and climate change reflected negatively on local industry. Wyoming University eventually capitulated to the pressure to remove the sculpture after receiving a number of threats that royalties the university received from the fossil fuel industry (through tax dollars) would be curtailed.

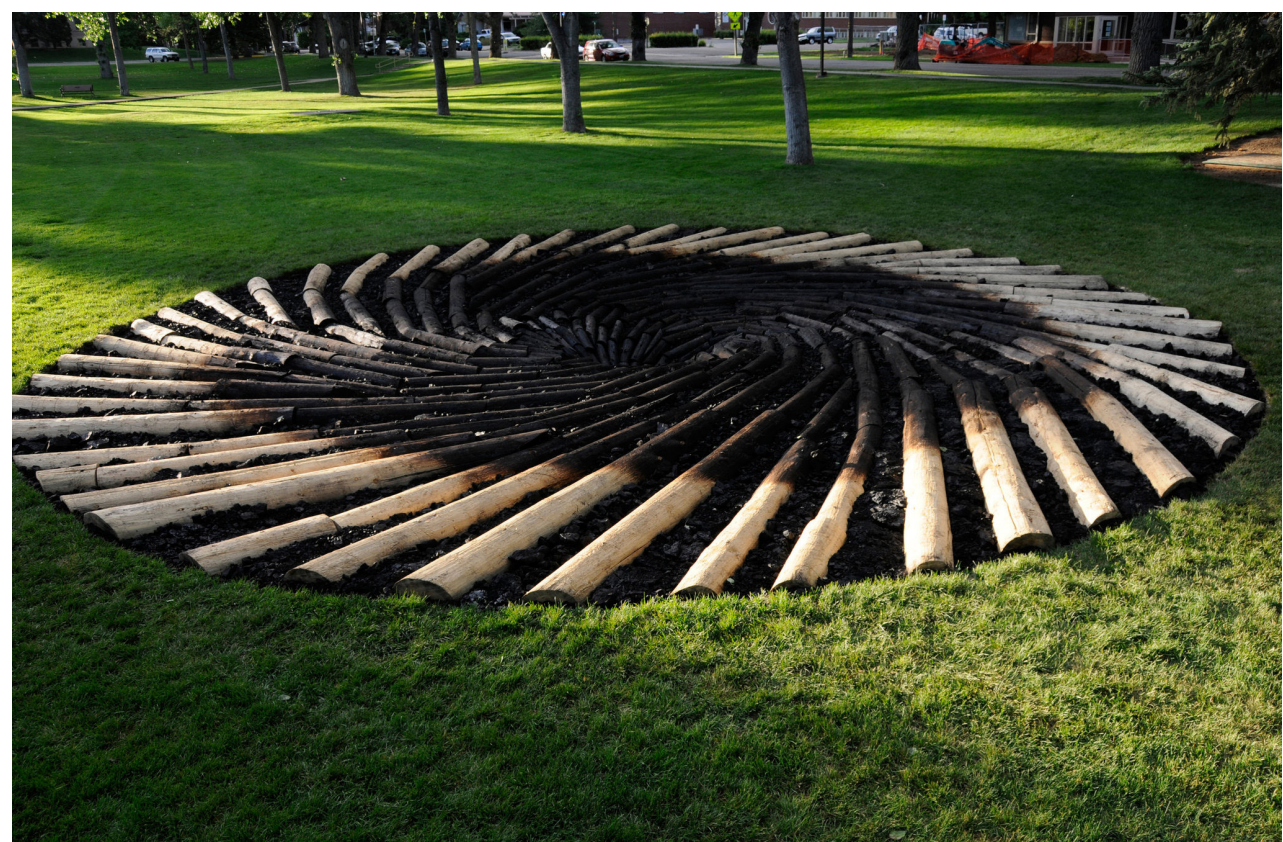

Fig. 1. Chris Drury, Carbon Sink: What Goes Around Comes Around, 2011. University of Wyoming campus, Laramie, USA. The installation was removed in May 2012.

The hold that corporations have over the public institutions they sponsor was recently evidenced in a legal battle initiated by the Request Initiative together with Platform against Tate, in order to 
force Tate to disclose details of its sponsorship agreement with BP. Despite numerous requests made over a ten-year period through the Freedom of Information Act, Tate had continuously refused to disclose these details on the grounds that to do so would purportedly be 'harmful to business interests' (cited in Lee 2011: 23). In all the tribunal lasted for three years. Finally, on 23 Dec 2014, Tate was given 35 days to reveal the value of BP's sponsorship between 1990 and 2007 together with details of 'internal decision-making' around the deal (Heasman 2015). In response to this ruling, Tate revealed that BP had donated a total of $£ 3.8$ million to Tate over this period. Its donations averaged $£ 224,000$ per year (given in annual amounts between $£ 150,000$ and $£ 330,000$ ), which according to Platform was an 'embarrassingly small' amount of funding in return for what BP are getting out of the arrangements (cited in Brown 2015).

There is another more insidious form of censorship, which although generally acknowledged, is even more difficult to prove: namely how curators self-censor for fear of jeopardizing corporate relationships. Jude Kelly, Artistic Director of the Southbank Centre (and my former boss), confirmed the existence of self-censorship among cultural professionals when she admitted that: 'Edicts from on high are not necessary; it functions more subtly, in an "everyone knows BP won't like this" kind of way' (cited in Evans 2015: 117). Such an episode of institutional self-censorship occurred at Tate Modern in 2010, when Tate attempted to preempt any criticism of its corporate sponsors that might arise from a workshop it had convened on art and activism called Disobedience Makes History. During the course of the workshop its organizers, The Laboratory of Insurrectionary Imagination, were issued with the following written communiqué by Tate: 'be aware that we [Tate] cannot host any activism directed against Tate and its sponsors' (cited in Rustin 2013). Although the participants had not planned to target any of the Tate's sponsors, their response to this act of censorship was the emergence of the artist collective Liberate Tate. A further instance of self-censorship was reported by the activist organization Platform, when the duty manager at the (Shell-sponsored) Southbank Centre refused to allow members of the group to distribute leaflets at an activity they were participating in as part of the London Literature Festival; for fear that the leaflets might contain any information that was critical of Shell (Lee 2011: 19).

While it is ultimately impossible to gauge the amount of censorship that takes place as a result of corporate sponsorship, the effect corporate sponsorship has on the type of art that is exhibited in public institutions and ultimately produced, is more readily apparent.

In order to get maximum publicity and thereby the best returns on their investments, corporate sponsors tend to favour spectacular commissions - like Tate Modern's Unilever Series - and blockbuster exhibitions and events, where they are guaranteed a large audience. In turn, this spectacle culture is self-perpetuating, where the cultural institution becomes dependent on external sponsorship in order to stage and market these incredibly expensive exhibitions, events and commissions. Furthermore, corporate sponsors tend to privilege high profile and more conservative institutions thereby artificially reducing the breath of the public cultural landscape by discriminating against smaller and niche institutions that target minority groups, and those with experimental or radical programmes. The exclusions perpetuated by corporate sponsorship of art and culture also extend to the geographical location of cultural institutions, where sponsors tend to favour institutions in capital cities and business centers where the impact of positive publicity is greater. In the case of BP, their cultural sponsorship is predominately directed towards national museums and galleries located in London.

\section{Opening interstitial distances in public cultural institutions}

The gradual privatization and corporatization of Europe's public cultural sector was a scenario predicted in a report entitled 'European Cultural Policies 2015: A Report with Scenarios on the Future of Public Funding for Contemporary Art in Europe', jointly commissioned by laspis, the European Institute for Progressive Cultural Policies (eipcp) and Åbäke as their contribution to 2005 Frieze Art Fair. To produce this report, eight cultural workers from different regions across Europe were each asked to forecast what the art funding landscape might look like in their particular region in 2015. ${ }^{8}$ Maria Lind gives the following summary of the participant's remarkably prescient predictions: 
In 2015 art is almost completely instrumentalized in the economic sense, regardless of whether financing is public or private. Art then services national or European interests that wish to construct a certain identity: it is a desirable marketable commercial good for private ownership and it contributes to regional development and provides society with new creative employment opportunities. Visiting art institutions is a popular, easily digested leisure activity (2005: 1).

While these predictions could be said to accurately reflect the type of public cultural sector championed by the neoliberal state, many of the researchers also allowed for the parallel emergence of critical collectives and institutions that experiment with alternatives to the dominant corporatized model of institutionalism. They forecasted that by 2015 such a critical approach will have 'found its own ways and means and established self-supporting microsystems' (Lind 2005: 1).

The critical alternatives to which Lind refers comprise of a wide variety of collectives of artists and activists that 'self-institute' their own non-hierarchical, bottom-up institutional forms. My focus here is limited to the coalition of collectives established in Britain since 2010 under the Art Not Oil banner and it is my intention to next examine the strategy of resistance they utilize.

Where radical leftwing strategies of resistance can be reduced to a choice between attempting to reform the cultural landscape from within (Chantal Mouffe's post-Marxist strategy of 'critique as hegemonic engagement with'), or abandoning it in order to establish alternative and autonomous institutions on the outside (the Autonomous Marxist strategy of exodus supported by Michael Hardt and Antonio Negri and Paolo Virno, amongst others), the collectives under discussion here refuse this dialectic. Instead they adopt what might be described, after Jacques Derrida (Bully 2007: 133), as a negotiated moving position between these two fixed positions, one which draws on aspects of both approaches.

This strategy arguably enables them to overcome some of the flaws inherent to these approaches. For example, when applied to the public art sector, Mouffe's (2008) post-Marxist strategy of 'critique as hegemonic engagement-with the state' (hereafter 'engagement'), describes critically political artistic practices and institutions that operate from within the public art sector and use its methods of dissemination in order to transform it into a site of counter hegemonic resistance. However, in order to adopt this position they need to be part of the institutional establishment, as was the case with the critical actors central to the Institutional Critique movement from the late $60 \mathrm{~s}$. This is not a position the collectives I discuss here hold within the public arts sector. They are predominately made up of emerging visual and performing artists, what Gregory Sholette (2014) describes as the artworld's 'dark matter', namely the anonymous masses that prop up the few that make it to the top of the artworld's shiny pyramid of success.

The counter-position to Mouffe's strategy of engagement is that of 'exodus', which follows the Althusserian rationale that all state institutions function as the administrative organs of the dominant ideology and, as such, are impervious to reform. This thinking is influenced by Gilles Deleuze's (1992) conception of the 'society of control', where mechanisms of control extends beyond the walls of physical institutions and become immanent to the social body, to the extent that the individual consciously internalizes and reproduces them.

In its application to the public cultural sector, a strategy of exodus would advocate the desertion of purportedly corrupt institutions like Tate and the establishment of bottom-up and self-organized extra-statal institutions in their place. This was never the intention of collectives like Liberate Tate or the Reclaim Shakespeare Company. As the names of these two collectives imply, their aim was not to boycott Tate or the Royal Shakespeare Company, but to liberate or reclaim these institutions from their association with BP. As such, their actions can be interpreted, not as an attack on these public institutions for their duplicitous value systems, but as acts of love for what they could be. Andrea Fraser makes a similar point with regard to the motivation behind Institutional Critique in the 60 s and 70 s, noting that Hans Haacke's critique was not an attack on the art institution but rather 'an attempt to defend the institution of art from instrumentalization by political and economic interests' (2006: 132). 


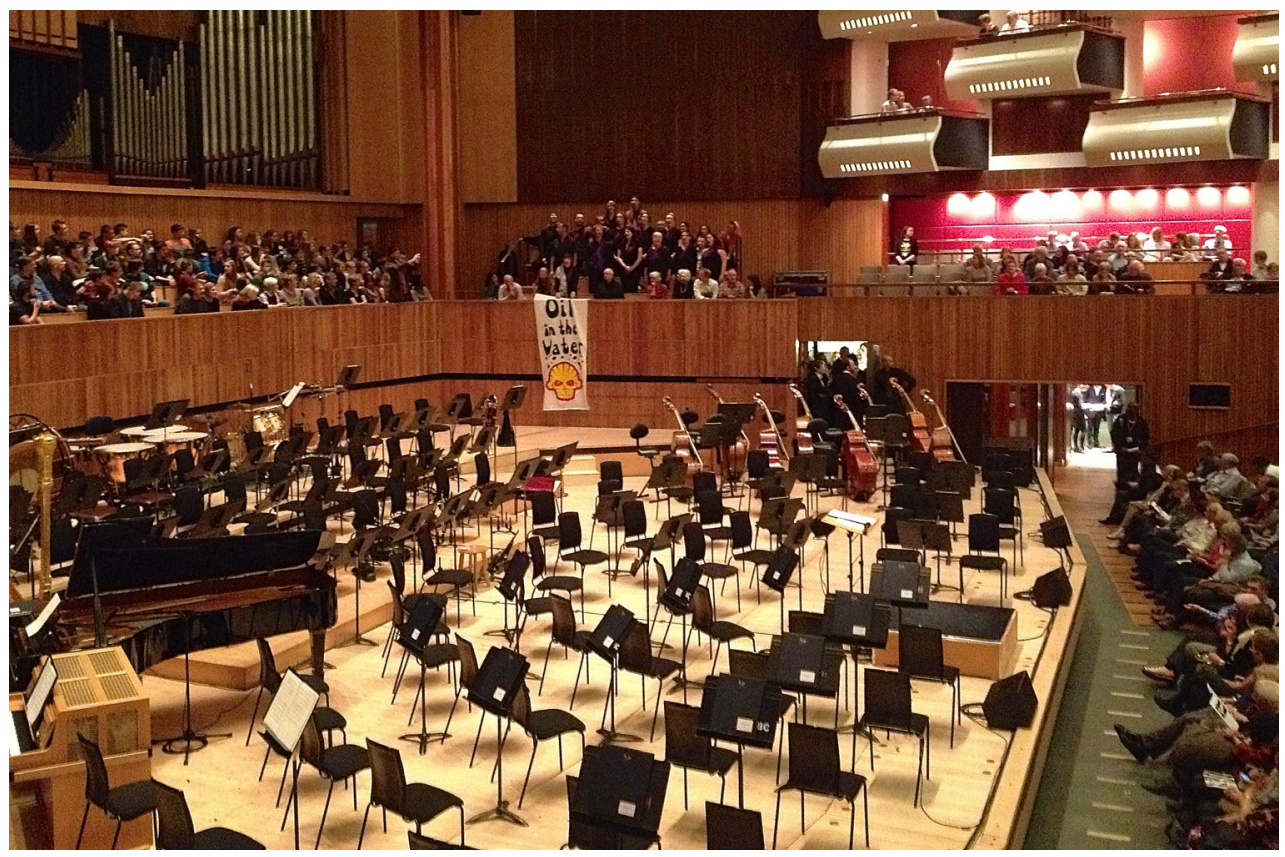

Fig. 2. Shell Out Sounds pop-up choir intervention at the Shell sponsored performance by the Sao Paolo Symphony Orchestra in the Royal Festival Hall, Southbank Centre, London, 2013. Photo by Hugh Warwick

To theorize the unique approach these critical collectives adopt, it is necessary to look to Critchley's meta-anarchic strategy of taking an interstitial distance to the state, which he sets out in the final chapter of Infinitely Demanding: Ethics of Commitment, Politics of Resistance (2007). Beginning from the premise that the state is an inevitable feature of the contemporary political landscape, Critchley proposes that the best course of action for radical politics is to operate within the state, but at an arm's length distance to it. He describes this distance as an interstitial or internal distance within state territory that needs to be opened from the inside with the goal of radically disturbing and undermining the machinations of the state from below. Unlike conventional politics, then, Critchley's strategy of interstitial distance is an antipolitics; it operates independently of state politics, but in tandem with it. This is an important distinction, because Critchley considers conventional (state) politics to be archic insofar as 'It is obsessed with the moment of foundation, origination, declaration, or institution that is linked to the act of government, of sovereignty, of establishing a state' (2007: 128). His antipolitics in contrast, is anarchic (Mahony 2014).

In its application to the public cultural sector, Critchley's anarchic political strategy provides a methodology for critical collectives and actors that do not conform to either of the ideologically entrenched positions of engagement or exodus, but instead operate from within, but at an internal distance to the public cultural institutions they target. To achieve this delicate balance they act like parasites, and employ instrumentalized cultural institutions as hosts. Stevphen Shukaitis (2009: 167) draws a similar analogy to describe how academics critical of the neoliberal university's politics, enact their dissent from a position that is 'within' but not 'of' the university. Otherwise put, they use the university's resources against the university.

Liberate Tate, for their part, used Tate as an unwillingly host for their critical actions against Tate. Shell Out Sounds staged choral performances in the auditorium of the Royal Festival Hall (2012-2013 and 2013-2014) during the Shell Classic International Series. In a similar fashion, The Reclaim Shakespeare Company commandeered the stage during the BP sponsored World Shakespeare Festival in 2012 in order to realize their guerilla Shakespeare 
interventions. When the Festival came to a close its members went on to form BP or Not BP, a collective that has staged interventions at BP sponsored events in the British Museum, the National Gallery and the Edinburgh International Festival. BP Out of Opera, the latest of these collectives to emerge, staged a performance in front of the BP Big Screens in Trafalgar Square just before a screening of a live performance of La Traviata.

The critical distance these collectives assume is underscored by the fact that, unlike Institutional Critique, which was often invited by the institution it was attacking, their actions are not sanctioned; they are entirely unauthorized interventions that take place on their own terms and without any prior notice.

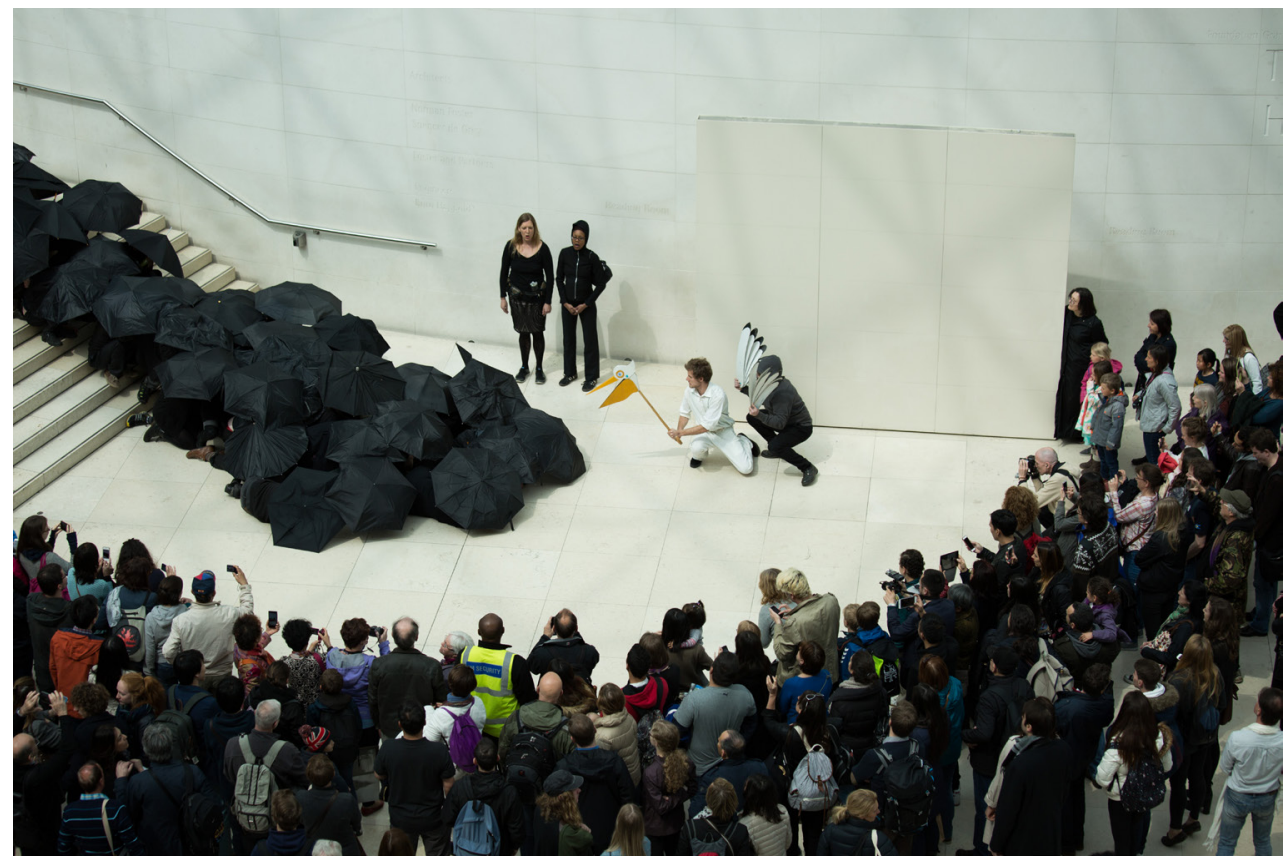

Fig. 3. BP or Not BP? in collaboration with Reverend Billy and the Stop Shopping Choir recreate Deepwater Horizon Oil Spill inside British Museum in protest at BP sponsorship, 2015. Photo by Kristian Buus.

Such a strategy necessitates a great deal of ingenuity, particularly when these collectives became well known to their host organizations and were effectively placed on watch lists. In many instances, smuggling their often sizable performance props past security guards proved to be the most challenging aspect of their actions. In the past Liberate Tate have concealed bags of an oil-like substance under the bouffant skirts of their party dresses (License to Spill, 2010); used insiders in Tate to assist them with smuggling canisters of the same oil-like substance into Tate Britain (Human Cost 2011); and concealed a 64-meter square of black cloth in a pram in order to get past the security guards at the entrance to Tate Modern (Hidden Figures 2014). In the case of their most impactful action, 100 members physically manhandled a one-anda-half ton, 16-and-a-half metre long wind turbine blade into the Turbine Hall at Tate Modern, carefully negotiating a team of security guards, one of whom lay down on the floor in front of them to hinder their entry (The Gift, 2012).

A further facet of their interstitial resistance is the manner in which these collectives use the vernacular of their host institutions as the medium of their performance actions. The Reclaim Shakespeare Company, whose members comprise of classically trained actors, scripted their protests in iambic pentameter and acted them out on stage in Shakespearian costumes. During a Shell sponsored concert by the Sao Paolo symphony orchestra, Shell Out 
Sounds', a 15-member choir delivered their protest message from their seats in the auditorium through the medium of song, reworking Wade in the Water to incorporate lyrics about Shell's environmentally destructive activities:

Oil in the water,

Oil in the water, children

Oil in the water

Shell's gonna trouble the water

Who's that yonder dressed in red?

Oil in the water

Must be the woman whose crops are dead

Shell's gone and burnt the Delta...

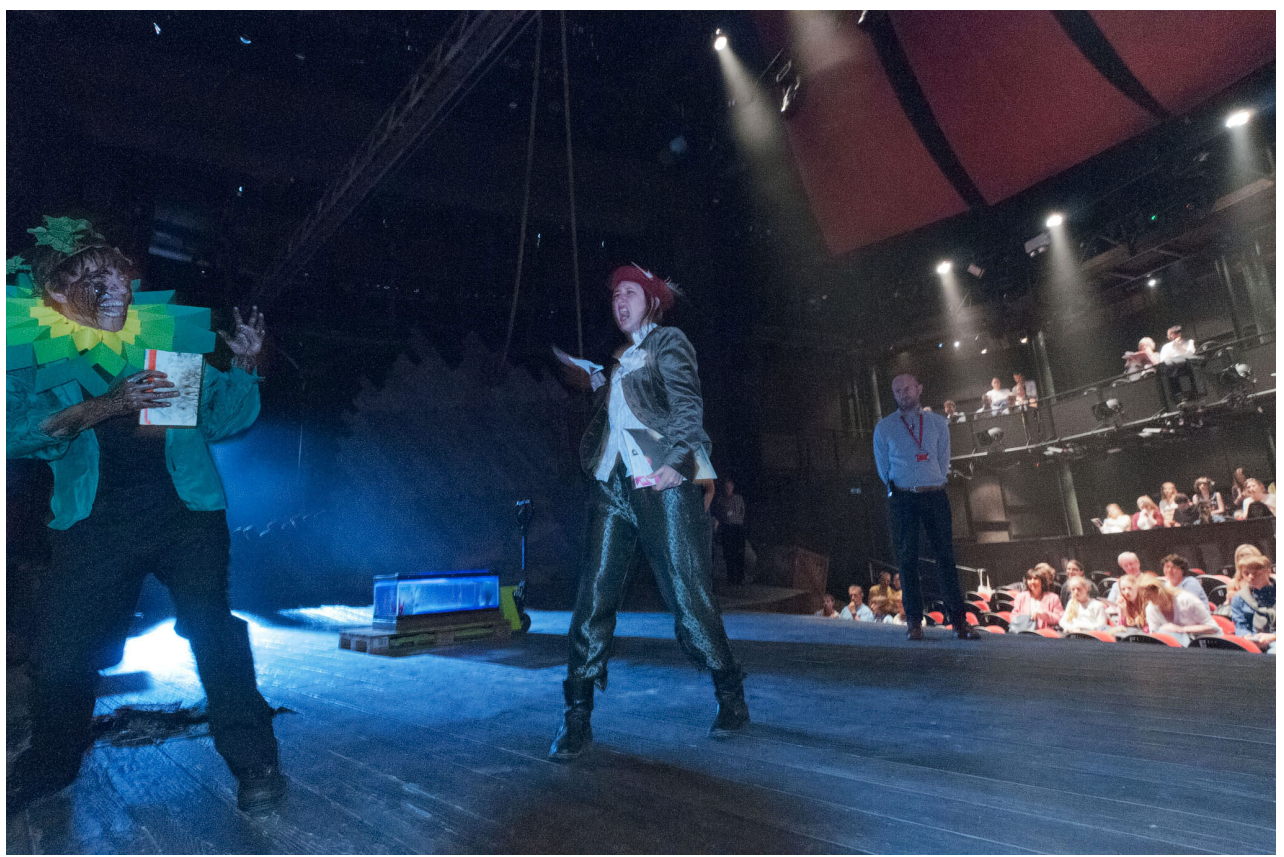

Fig. 4. The Reclaim Shakespeare Company (now known as BP or not BP?) performing a guerilla Shakespeare action on stage at the Roundhouse Theatre, Camden, 2012. Photo by David Hoffman.

Liberate Tate, for their part, focus on live art, which is one of Tate's major programming strands, as is evidenced by their BMW Tate Live series, and the more recent opening of The Tanks at Tate Modern in 2012 - a new subterranean gallery space dedicated to staging sound, moving image and live artworks. In the case of Human Cost (2011), Liberate Tate staged a live artwork in the middle of the BP sponsored exhibition Single Form: The Body in Sculpture from Rodin to Hepworth in Tate Britain. Given that the Tate exhibition focused on representations of the human form, Liberate Tate's unauthorized addition was not out of place, and many unsuspecting viewers assumed it to be part of the programme until security guards intervened and cordoned off the performers. For Hidden Figures (2014), which took place at Tate Modern during the Kazimir Malevich retrospective, performers and passers-by took turns to create shapes and poses beneath a 64-meter square piece of black cloth, which was held aloft by members of Liberate Tate. The fabric square evoked both a three-dimensional interpretation of Malevich's 


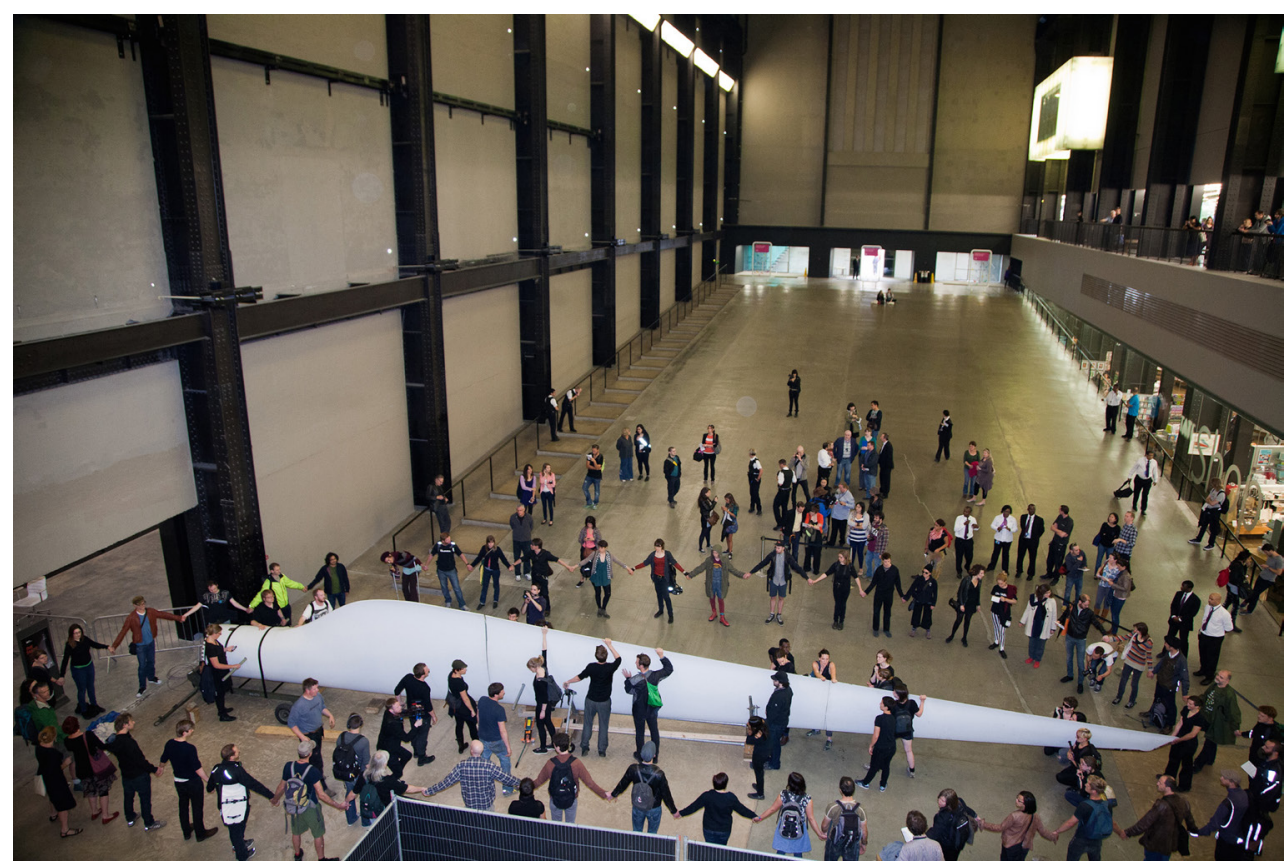

Fig 5. Liberate Tate, Gift, 1-and-a-half ton, sixteen-and-a-half metre long wind turbine blade. Performed in the Turbine Hall at Tate Modern, 2012. Photo by Martin Le Santo-Smith.

iconic painting Black Square (1915) (which was on display in the adjacent galleries), and the solid black squares Tate had used to redact text that set out details of its sponsorship agreement with BP, when asked for this information through a freedom of information request made jointly by Platform and The Request Initiative.

The strategy of using their hosts' language sets these collectives apart from other fossil fuel protest groups. While the latter operate like an irritant, targeting and harassing individuals within oil corporations or picketing their head quarters, these collectives firmly believe that aesthetics combined with activism can achieve more than activism alone. Moreover, by speaking the same language as the art and culture lovers whose solidarity they are seeking to galvanize, these critical collectives can more effectively articulate their protest message. Liberate Tate's action The Gift (2012) played on their role as a by then well-recognized art collective with high profile press coverage, by offering to donate a work to the Tate's permanent collection, which Tate's board then had to consider and either accept or reject. ${ }^{9}$ The work in question comprised a wind turbine blade, together with documentation of the performance Liberate Tate staged when 100 members of the group carried the blade, which had been cut into three pieces, into the Tate Modern's turbine hall and resembled it in situ. Although three months later (after having to store the blade at their own cost) Tate ultimately rejected The Gift, they took the decision to put the documentation accompanying it into their archive, thereby acknowledging and ratifying both Liberate Tate's status of artists worthy of recognition by Britain's foremost contemporary art gallery, and their critique of Tate for its sponsorship agreement with BP.

The opening of spaces of dissent from below is also evident in how the interventions of these critical collectives create temporary counter public spheres within their host organizations that cast doubt on normative and dominant opinions and narratives regarding the role of Big Oil sponsorship currently plays in the public cultural sector. These temporary counter public spheres are formed when the audiences and participants of these actions respond to the alternative narratives these collectives publish. A paradigmatic example can be found in Liberate Tate's Parts Per Million (2013), which offers an alternative and counter-critical reading of the 2013 rehang of Tate Britain's permanent collection galleries under the title 'BP Walk Through 
British Art'. Responding to Tate's chronological hang in rooms depicting worked from the 1840 s to the 2000 s, Liberate Tate staged an action on the opening day involving a spoken choir that moved chronologically through the gallery spaces counting the increase in carbon dioxide particles in the atmosphere associated with that decade. Liberate Tate's alternative narrative sought to bring to public attention the role fossil fuels have played in climate change since the Industrial Revolution. When they reached the gallery displaying work created in the 2000s, the tally reached 400 particles in the atmosphere, exceeding by 50 that which is believed to be safe by leading climate scientists. In 2015 Liberate Tate returned to the 'BP Walk Through British Art' galleries to execute numerical tattoos on members of the group and willing participants that expressed the number of carbon dioxide particles in the atmosphere in the year they were born. Titled Birthmark (2015), the action sought to draw an analogy between the permanency of a tattoo and that of climate change, neither of which can be completely

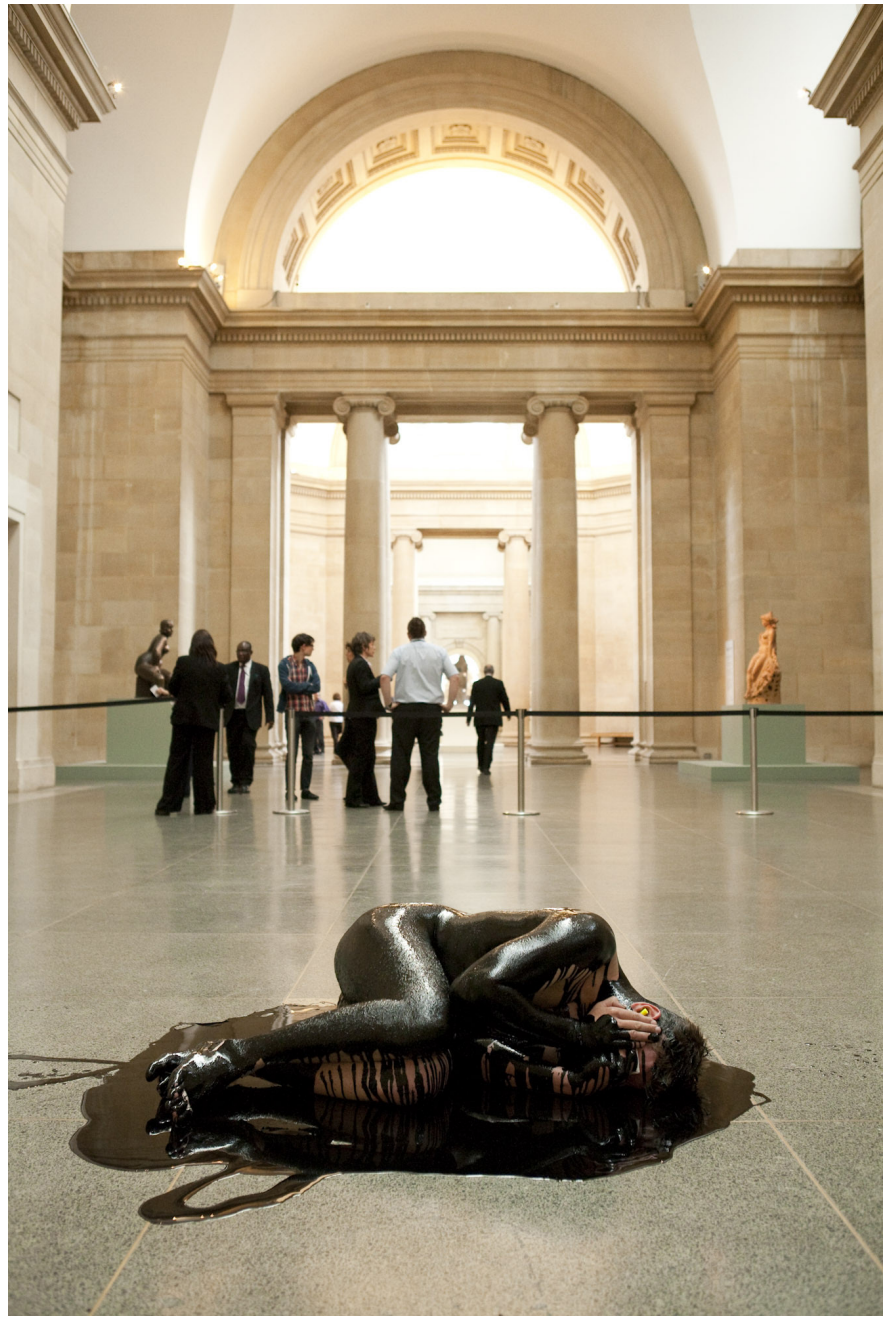

Fig. 6. Liberate Tate, Human Cost, 87 minutes, sunflower oil and charcoal. Performed in the exhibition Single Form: The Body in Sculpture from Rodin to Hepworth at Tate Britain on 20 April, 2011, the first anniversary of the Deepwater Horizon explosion reversed. The success

and longevity of the counter public spheres Liberate Tate create in response to their actions is greatly assisted by the extensive press coverage they illicit and the parallel debates they inspire on social media platforms.

\section{Conclusion: A slow war of position}

The interstitial strategy of resistance these collectives employ has resulted in a number of concrete victories. In January 2014, the South Bank Centre (my former employer) discontinued its eight-year sponsorship relationship with its close neighbour Shell. In March 2016, BP announced that their 26-year sponsorship agreement with Tate would cease in 2017 and one month later they also announced the cessation of their 34-year sponsorship agreement with the Edinburgh International Festival. However, in all of the above instances, neither the 
cultural institutions involved, nor their former oil company sponsors are willing to admit that their decision was in any way influenced by the sustained actions of these critical collectives. BP simply attributes their decision to withdraw from Tate and the Edinburgh International Festival to 'an extremely challenging business environment' (Clark 2016).

Despite the denials, these results are real and were hard won. However, they only represent small victories in a much bigger battle. Although they have severed their ties with Tate and the Edinburgh International Festival, BP recently signed a new sponsorship deal with the British Museum, the National Portrait Gallery, Royal Opera House and the Royal Shakespeare Company for $£ 7.5$ million, continuing BP's instrumentalization of Britain's cultural landscape for the next five years at least. Other Big Oil companies have also entered the cultural sponsorship arena with Statoil sponsoring the new WonderLab Gallery at The London Science Museum, which opened in October 2016 to extensive criticism including an open letter in the Guardian calling on the museum to drop its sponsorship that was signed by scientists, academics and educations. ${ }^{10}$

Responding to BP's announcement, members of BP or Not BP and Liberate Tate have stated that they remain committed to the cause and vow to 'challenge and overturn' BPs new sponsorship deal. Such a response shows that they are patently aware that such a goal must involve what Antonio Gramsci called a 'war of position', namely the slow and systematic dismantling of these public cultural institutions from the deep-rooted neoliberal value system with which they are intermeshed. By acting as parrhesiates and exposing the incommensurability between the good account these public cultural institutions give of themselves and their actual deeds, these collectives can slowly, but surely overturn these values.

Another point that Gramsci emphasized was the importance of achieving what he called a 'coalition of opposition', attributing the failure of the workers' revolts in Europe at the start of the twentieth century to the fact that the workers failed to form coalitions with other subordinate groups (Jones 2006: 42-3, 130). In the case of the collectives I discuss here, not only do they collaborate and support each other through the Art Not Oil coalition (with several individuals being members of multiple collectives), but they also forge chains of equivalence with other critical collectives including Global Ultra Luxury Faction (GULF) and Gulf Labour Coalition (GLC), both of whom advocate for migrant worker rights in the construction of a franchise of the Guggenheim on Saadiyat Island in Abu Dhabi. They also collaborate with and support activist groups and social movements including Occupy and its splinter groups. Moreover, they are engaged in solidarity work that extends well beyond the single issue of the fossil fuel industry instrumentalizing cultural institutions to more broadly incorporate both the privatization of public institutions, and social justice in general.

Received: 8 September 2016

Finally Accepted: 3 July 2017

\section{Notes}

1 Tate Modern hosted the eco-symposium Rising to the Climate Challenge: Artists and Scientists Imagine Tomorrow's World in 2010.

2 See 'BP: Corporate Rap Sheet', Corporate Research Project, http://www.corp-research. org/BP accessed 10 March 2017.

3 A further facet of this debate is the growing competition public cultural institutions face from private museums established by very wealthy individuals to house their private collections. In the past 20 years the growth of these private museums across Europe has been exponential including among others: François Pinault's two galleries on the Grand Canal in Venice - the Palazzo Grassi (2007) and the Punte della Dogana (2009); Frank Cohen's private gallery Initial Access (2007) in Wolverhampton and the Zabludowicz Collection (2007) in North London; and the Hoffman (opened 1997), Haubrok (2002), Boros (2008) and Feuerle (2016) collections, all in Berlin.

4 The exhibitions to which I refer here include Panamarenko (2000), Brassaï (2001) and Ann-Sofi Siden's Prostitution after the Velvet Revolution (2002). 
5 Here I am specifically referring to exhibitions like Saved! 100 Years of the National Art Collections Fund (2004), and Blind Light, the 2007 Anthony Gormley retrospective.

6 See Kevin Smith and Clayton Thomas Muller, 'Social License: Complicity in the Age of Extraction', Platform London, 15 March 2012 http://platformlondon.org/p-article/sociallicence-complicity-in-the-age-of-extraction/, accessed 12 March 2016.

7 This is not the first time Tate has entered into a title sponsorship agreement, precedents include The Unilever Series and BMW Tate Live.

8 The researchers were Rebecca Gordon Nesbitt (Scotland), Branca Curcic (Serbia and Montenegro), Cornelia Sollfrank (Berlin), Hüseyin BahriAlptekin (Turkey), Frédéric Jacquemin (Belgium), Oleg Kireev (Russia) and Tone Hansen (Norway) (Lind 2005).

9 The work utilized Section 7 of the Museum and Galleries Act of 1992 whereby Tate was legally obliged to consider the gift for their permanent collection.

10 The Guardian, 'Science Museum should drop Statoil sponsorship of children's gallery', Letters, Monday 10 October 2016, https://www.theguardian.com/environment/2016/ oct/10/science-museum-should-drop-statoil-sponsorship-of-childrens-gallery, accessed 19 February 2017.

\section{References}

Brown, M. (2015) 'Tate's BP sponsorship was $£ 150,000$ to $£ 330,000$ a year, figures show', The Guardian, 26 January https://www.theguardian.com/artanddesign/2015/jan/26/ tate-reveal-bp-sponsorship-150000-330000-platform-information-tribunal, accessed 23 February 2017.

Bully, D. (2007) ‘Ethical Assassination? Negotiating the (Ir)responsible Decision', in Madeleine Fagan, Ludovic Glorieux, Indira Hasimbegovic and Marie Suetsugu (eds), Derrida: Negotiating the Legacy, 128-42, Edinburgh: Edinburgh University Press.

Butin, H. (1998) 'When Attitudes Become Form Philip Morris Becomes Sponsor: Arts sponsorship in Europe against the background of developments in America', Society of Control http://www.societyofcontrol.com/research/butin engl.htm, accessed 3 March 2017.

Clark, N. (2016) 'BP to end controversial sponsorship of Tate in 2017', Independent, 11 March, http://www.independent.co.uk/arts-entertainment/art/news/bp-to-endcontroversial-sponsorship-of-tate-in-2017-a6923471.html accessed 8 February 2017.

Clarke J., Evans, M., Newman, H., Smith, K. and Tarman G. (2011) Not if but when: Culture Beyond Oil, London: Art Not Oil, Liberate Tate and Platform, London: Platform.

Critchley, S. (2007) Infinitely Demanding: Ethics of Commitment, Politics of Resistance, London and New York: Verso.

Davies, A. (2012) 'Take Me I'm Yours: Neoliberalising the Cultural Institution', in Zoran Eric and Stevan Vukovic (eds), Precarious Labour in the Field of Art, On Curating 16 (13) 26-38 http://www.oncurating-journal.org/index.php/issue-16.html\#.UkF11GREQmQ accessed 5 December 2016.

Deleuze, G. (1992), 'Postscript on the Societies of Control', October, 59 Winter 3-7.

Evans, M. (2015) Artwash: Big Oil and the Arts, London and New York: Pluto Press. 
Fraser, A. (2006) 'From the Critique of Institutions to an Institution of Critique' in J. C. Welchman (ed), Institutional Critique and After, 123-36, Zurich: JRP Ringier.

Heasman, R. (2015) 'Tribunal Rules that Tate Must Reveal Price of BP Sponsorship', DESMOGUK, 6 January http://www.desmog.uk/2015/01/06/tribunal-rules-that-tatemust-reveal-price-of-bp-sponsorship accessed 29 January 2017

Hewison, R. (2014) Cultural Capital: The Rise and Fall of Creative Britain, London and New York: Verso.

Jelinek, A. (2014) This is Not Art: Activism and Other 'Not-Art', London and New York: I. B. Tauris.

Jones, J. (2010) 'Tate is right to take BP's money', Jonathan Jones on Art Blog, The Guardian, 29 June http://www.theguardian.com/culture/jonathanjonesblog/2010/ jun/29/tate-bp-sponsorship, accessed 29 January 2017.

Jones, S. (2006) Antonio Gramsci, Routledge Critical Thinkers, London and New York: Routledge.

Lee, M. (2011) 'Platform: attempting to drive a wedge between Tate Modern and BP', The Ecologist, 18 February http://www.theecologist.org/campaigning/climate change and energy/777665/platform attempting to drive a wedge between the tate modern and bp.html, accessed 2 March 2017.

Lind, M. (2005) 'European Cultural Policies 2015: A Report with Scenarios on the Future of Public Funding for Contemporary Art in Europe', eipcp http://eipcp.net/policies/2015/ lind/en/print, accessed 14 January 2017.

Mahony, E. (2014) 'Locating Simon Critchley's "interstitial distance" in the practices of the Freee Art Collective and Liberate Tate', Art \& the Public Sphere, 3 (1) 9-30 http:// www.intellectbooks.co.uk/journals/view-Article, id=19695/, accessed 5 December 2016.

McNicholas, B. (2004) 'Arts, Culture and Business: A Relationship Transformation, a Nascent Field', International Journal of Arts Management, 7 (1) 57-68.

Miliard, C. (2012) 'Liberate Tate's Spokesman on Why Fighting BP Sponsorship Picks Up the Cause of Tahrir Square', BLOUIN ARTINFO, 4 January http://www.blouinartinfo. com/news/story/755049/liberate-tates-spokesman-on-why-fighting-bp-sponsorshippicks\#, accessed 9 January 2017.

Möntmann, N. (2006) 'The Enterprise of the Art Institution in Late Capitalism', (Translated by Aileen Derieg), eipcp http://eipcp.net/transversal/0106/moentmann/en, accessed 5 February 2017.

(2008) 'Playing the Wild Child. Art Institutions in a Situation of Changed Public Interest', in Jorinde Seijdel (ed), Art as a Public Issue: How Art and Its Institutions Can Reinvent the Public Dimension, Open, 14 1-10, Rotterdam: NAi publishers file:/l/ Users/emmamahony/Downloads/Playing\%20the\%20Wild\%20Child.pdf, accessed 5 February, 2017.

Mouffe, C. (2008) 'Critique as Counter-Hegemonic Intervention', eipcp http://translate.eipcp. net/transversal/0808/mouffe/en, accessed 7 February 2017.

Rustin, S. (2013) 'Can Liberate Tate free the arts from BP?', The Guardian, 14 April http:// www.theguardian.com/artanddesign/2013/apr/24/liberate-tate-arts-bp, accessed 29 January 2017. 
Saner, E. and Khaleeli, H. (2010) 'Crude awakening: BP and the Tate', The Guardian, 30 June http://www.theguardian.com/artanddesign/2010/jun/30/bp-tate-protests, accessed 5 December 2017.

Sholette, G. (2014) Dark Matter: Art and Politics in the Age of Enterprise Culture. London and New York: Pluto Press.

Shukaitis, S. (2009) 'Infrapolitics and the nomadic educational machine', in Randall Amster, Abraham DeLeon, Luis Fernandex, Anthony J. Nocella and Deric Shannon (eds) Contemporary Anarchist Studies: An Introduction to Anarchy in the Academy, 16674, New York: Routledge.

Smith, K. (2012) 'US artwork that angered energy industry pulled - could it happen here?', Index on Censorship, 16. Novemberhttps://www.indexoncensorship.org/2012/11/ energy-donor-artistic-freedom-censorship/, accessed 5 January 2017.

Trowell, J. (2013) Take the money and run?: Some positions on ethics, business sponsorship and making art, A Live Art Development Agency Study Room Guide, London: Platform.

Webb, T. (2010) 'BP boss admits job on the line over Gulf oil spill', The Guardian, 14 May http://www.theguardian.com/business/2010/may/13/bp-boss-admits-mistakes-gulfoil-spill, accessed 10 February 2017.

Wu, C. (2003), Privatising Culture: Corporate Art Intervention since the 1980s, London and New York: Verso.

*Dr. Emma Mahony is a lecturer in the School of Visual Culture at the National College of Art and Design, Dublin. Her research investigates the relationship between contemporary art, curatorial studies, radical pedagogy and activism, instituting conversations with radical philosophy and public sphere theory, to propose methodologies for artist's collectives that seek to rewrite the neoliberalization of the cultural landscape and the public university. From 2004-8 she was exhibitions curator at the Hayward Gallery, Southbank Centre London.

15 Rossana Close

Ballinalea

Ashford

Co. Wicklow

A67 K036

Rep. of Ireland

mahonye@staff.ncad.ie emma.mahony@gmail.com

Telephone: 00353 (0)86 2070335 